\title{
A fuzzy-TOPSIS approach for techno-economic viability of lighting energy efficiency measure in public building projects
}

\author{
Khadeejah Adebisi Abdulsalam ${ }^{a}$, Desmond Eseoghene Ighravwe $\mathrm{b}^{\mathrm{b}^{*}}$ and Moses Olubayo Baba- \\ tunde $^{\mathrm{a}}$
}

${ }^{a}$ Department of Electrical and Electronics Engineering, University of Lagos, Nigeria

${ }^{b}$ Department of Mechanical Engineering, Ladoke Akintola University of Technology, Nigeria

\section{H R O N I C L E}

\section{Article history:}

Received: November 5, 2017

Received in revised format: February 20,2018

Accepted: April 2, 2018

Available online:

April 2, 2018

Keywords:

Lighting technology

Techno-economic criteria

Public buildings

Decision making

TOPSIS

\section{A B S T R A C T}

Retrofitting technologies have helped to manage energy consumptions in residential, public and industrial buildings. However, understanding of the technical and economic considerations for selection of appropriate retrofitting technology is still evolving and divergent. Thus, this study presents a framework that combines techno-economic requirements as a means for evaluating the important retrofitting criteria and suitable lighting retrofit technologies for building projects. The framework is hinged on the unique features of entropy fuzzy and TOPSIS (Technique for Order of Preference by Similarity to Ideal Solution) methods. The analysis of the lighting technology selection was performed from technical, economic and techno-economic perspectives. During the application of the proposed framework, four lighting technologies (CFL, T5, E-ballast and T8-electronic) and nine techno-economic criteria were considered. The most and least important techno-economic criteria for the case study were net present value and electricity saved, respectively. The least and most suitable retrofitting technologies were T8-electronic and CFL, respectively, from techno-economic perspective. T5 and T8-electronic were identified as the most suitable lighting technologies from an economic and technical perspectives, respectively. This discrepancy in the results justified the need for the techno-economic approach for the retrofitting technologies evaluation.

\section{Introduction}

The cost of providing electricity in an organisation is often the second highest expenses that constitute the running costs of most organisations in developing countries. Also, a significant amount of electricity (20-30\%) are used for lightening purpose in most organizations. Hence, research efforts geared towards reducing this have been ongoing with some positive results. Electricity is the main backbone of the modern world and its generation and consumption affect a country's productivity. The issue of its generation has been extensively considered in literature (Chaudhuri \& Lovley, 2003; Liu \& Logan, 2004; Súri et al., 2007). This has made current efforts to focus on the need to provide green energy using renewable energy sources (Herzog et al., 2001; Panwar et al., 2011; Babatunde et al., 2018a, b). Since 
there are limited resources to deploy renewable energy to every nook and crannies of a community, governments are welcoming the use of hybrid energy sources and demand-side management techniques. This has helped to mitigate energy poverty in most developing countries.

However, decision-makers are expected to consider the peculiar characteristics of an environment where such hybrid energy systems are to be deployed (Liserre et al., 2010). This is necessary in order to obtain the optimal combination of energy source for a hybrid energy system in a community. Also, to improve the ease of integration of green energy into a power grid system of a community, decisionmakers carry out multi-criteria analysis of renewable energy sources (Alepuz et al., 2006). The desire to integrate green energy into a national grid system is to reduce the amount of $\mathrm{CO}_{2}$ and other gases that are emitted into the atmosphere from the use of conventional energy sources (Omer, 2010; Oyedepo, 2012). Commercial and residential usage of conventional energy sources has done a lot of damage to our environment such that governments and non-governmental organisations are now designing different programmes to bring the awareness of the damages caused by conventional energy source to everybody's attention. One of such is the advocacy for energy efficiency and conservation methods and also a shift in the dependency on conventional energy sources to renewable technology. Consequently, there are attempts to develop renewable energy technology to generate electricity to power equipment such as laptops, street lights, electric lamps in residential and commercial buildings.

Researchers have now taken the issue of energy efficiency by using energy saving lamps to design new building projects, while recommending these lamps as replacements for non-energy saving lamps in existing buildings.. This is necessary to reduce energy consumption, $\mathrm{CO}_{2}$ emission and lamp life span. In commercial and residential consumption, lighting accounts for $20-30 \%$ of total consumption, hence replacing lighting technology with energy efficient technology can result in substantial saving in electricity consumption and hence savings in electricity expenses and environmental preservation (al Irsyad \& Nepal, 2016; Di Stefano, 2000; Ganandran et al., 2014; Li et al., 2010). However, there exists sparse information on the application of multi-criteria tools for the evaluation of lighting technologies that can be adopted in public buildings. Current decisions on this issue are based on the use of a single performance index, which can be a technical (lamp rating) or economical (net present value) criterion. This approach is common in developing such as Nigeria, where the issue of power generation and consumption is a major challenge for facility managers and policy-makers.

Most public buildings in developing countries are originally fitted with incandescent lamp -a lamp based on the principle of incandescence, in which solids and gases emit visible light when burning or when an electric current heats them to a sufficiently high temperature. Each material gives off a light in a colour characteristic of that material. The most familiar example of an incandescent lamp is the common household bulb. The efficiency of an incandescent lamp is less than $20 \%$. Recently, most of these incandescent lamps have been replaced with fluorescent, which consumes less energy and is more efficient, however, at low temperatures, some fluorescent lamps do not perform well, they are not resistant to internal shock, and contain mercury which is a potential pollution hazard. To adequately address the issue of light technology selection in developing countries, there is the need for empirical studies which consider technical, economical and techno-economic criteria for this problem. Such studies are expected to explore the need for different light technologies with respect to the decision from different experts.

Based on the above-mentioned gaps, this study combines entropy fuzzy and TOPSIS (Technique for Order of Preference by Similarity to Ideal Solution) methods in presenting a framework for the selection of the most suitable lighting technology in public buildings. The framework explored the use of technical, economic and techno-economic criteria in the evaluation of lighting technology for public buildings. This approach is considered in order to provide decision-makers with opportunities of a different course of action with respect to their overall aim of selecting a lighting policy. 


\section{Literature Review}

Several efforts have been made to assess the broader benefits and costs of the energy efficiency improvements on lighting systems across the globe (Kumar et al., 2013; Mills \& Schleich, 2014; al Irsyad $\&$ Nepal, 2016). For instance, al Irsyad and Nepal (2016) proposed a unique two-step methodology for a street light system in Indonesian cities. In the first method, the actual conditions of street lighting systems in the cities were surveyed and the performance of a pilot project in one of the cities was estimated. The second method involved the estimation of the national benefits and costs of energy efficiency improvements in street lighting by decomposing the benefits and costs into each energy efficiency action. Here, replacing old lamps with new high efficient ones resulted in less than two years pay back period. They suggested the use of adaptive lighting technology that responds to traffic intensity or real-time sensing. Their study advocated metering of electricity consumption and showed that adequate metering resulted in a 16\% decrease in utility bills. Lamp replacement also gave a reduction of $58 \%$ and the use of an adaptive lighting system led to $68 \%$ reduction which ultimately results in Green House Gas. Mills and Schleich (2014) evaluated the factors that affect the use of compact fluorescent lamps (CFLs) and light-emitting diodes (LEDs) as a replacement for old incandescent lamps (ILs). The outcomes of their study showed that placing banning on the use of non-energy efficient lamps will help to increase the compliance of the use of energy efficient lamps. However, this decision may not be effective in low income communities, especially in developing countries (Kumar et al., 2013). But, proper awareness of the populace will lead to a substantial improvement in the acceptance of energy-efficient technologies (Kumar et al., 2003). Okoro et al. (2008) reported a study that evaluated the awareness programmes on energy efficiency among academic staff in a university system. The essence of their study was to identify how constant power supply can be sustained in a university system. The outcomes of their study showed that the provision of an incentive for the use of energyefficient equipment will enhance electricity availability. The adoption of energy efficient technologies in building helps to reduce the amount of peak load of such facility (Kumar et al., 2003).

Li et al. (2010) analysed how energy demand of non-residential buildings can be managed through the use of energy-efficient light fittings and control. They observed that energy savings can be achieved through the selection of appropriate photovoltaic lighting control for a building. Mahila et al. (2011) evaluated the use of lighting retrofit in a university system using pay back period and life cycle cost. Their work compared the performance of T5, T8 electronic and HPT8 system as alternatives to an existing T8 on the basis of life cycle cost, energy saving and energy cost. They observed that T5 was the best lighting retrofitting for their case study. Enongene et al. (2017) addressed the issue of residential lighting efficiency from the perspectives of energy saving, environmental and economic benefits. They studied the economic benefits of using CFL and LED to replace incandescent lamps. Their study did not only experience improvement in net present value and life-cycle cost, there was also a reduction in the amount of green gas emission when incandescent lamps were replaced with CFL and LED. LED was proposed as the replacement for the traditional lighting technologies consisting of CFL two pin bulbs and fluorescence tubes in some buildings at the Universiti Tenaga Nasional on a scale of 10\% retrofit yearly to span ten years (Ganandran et al., 2014). They also attempted to estimate the potential electricity savings based on 8-hr daily, 5-day weekly operating period, the pay back period for returning the investment using life cost analysis and potential environmental benefit derived from consuming less energy by estimating the reduction in gaseous emissions. The choice of LED was based on the premise that it uses $80 \%$ less energy than incandescent and 30 to $40 \%$ than most fluorescent lamps (Mills \& Schleich, 2014; Ganandran et al., 2014).

LEDs are considered as environmental friendly products since they are mercury free, but CFL contain mercury and need special disposal or recycle approach, which classifies it as hazardous waste. LED sources may last longer than traditional technologies which can save costs on replacement and maintenance. LEDs offer illumination without emitting harmful infrared or ultraviolet radiation. Also, retrofitting with LED is seamless since the interface is interchangeable with that of CFL two pin bulbs and fluorescence tubes. This will lead to an annual potential saving of $41 \%$ of electricity consumption and 
the pay back period is approximately four years and ultimately reduce gaseous emissions to the environment. Abolarin et al. (2013) presented similar results when the incandescent lamps in students' hostels in the University of Lagos, Nigeria were retrofitted with compact fluorescent lamps. In addition to a reduction in electricity consumption, there was a $45 \%$ reduction in carbon dioxide emission.

Di Stefano (2000) evaluated the possibility of reducing electricity consumption and carbon dioxide emission in the Melbourne University. Their work considered four energy efficient lighting technology alternatives by estimating the cost-effectiveness of the lighting technology alternatives. The results obtained showed a potential of electricity saving when a 1.2 metre fluorescent lighting fixtures were replaced with new energy efficient lighting technology. However, the exorbitant cost of installing new technology was a major hindrance. They observed that reduction in electricity consumed also impacted by reducing cooling load since heat emission is reduced. Ahmad et al. (2012) presented a report on an energy management program carried out at the Faculty of Electrical Engineering, Universiti Teknologi Malaysia through an energy saving campaign. Their work observed an attitudinal changes that resulted in a reduction in total annual energy consumptions with its attendant effects. Trifunovic et al. (2009) study reported the reduction in electricity consumption when incandescent lamps were replaced with a compact fluorescent lamp in Belgrade. There was also a decrease in electricity required for cooling, which ultimately led to decline in electrical energy importation.

Based on the papers that were reviewed, it is obvious that the study of energy study in a building can be effectively considered under a multi-criteria approach. However, there is sparse information on the aggregation of experts' judgment for a non-residential building. For instance, the benefit of using multicriteria tools in energy study was demonstrated by Ighravwe and Babatunde (2018). They attempt to identify a renewable energy business model for developing countries. Their study combined technoeconomic and environmental criteria in selecting a business model for a remote community in Nigeria under a fuzzy condition. The unique properties of fuzzy logic, CRITIC (Combines Criteria Importance through Inter-criteria Correlation and TOPSIS (Technique for Order Performance by Similarity to Ideal Solution) were used to identify a private-based mini-grid business model for their case study.

\section{Methodology}

The proposed framework for the lighting technology problem is based on the use of entropy fuzzy method for criteria weight importance evaluation, while a TOPSIS method is used to rank potential lighting technologies for a building.

\subsection{Entropy fuzzy method}

Entropy fuzzy method is an approach which has the unique property of using fuzzy number to determine criteria importance during multi-criteria analysis. This approach converts linguistic values to fuzzy numbers (Table 1). In Table 1, an instance of the evaluation of lighting technology for a university senate building in Nigeria is considered using an intuitionistic fuzzy number (see Shahmardan and Zadeh, 2013).

\section{Table 1}

Linguistic expressions for the criteria importance evaluation

\begin{tabular}{lcccc}
\hline Linguistic expression & Symbol & $u_{i j}$ & $v_{i j}$ & $\pi_{i j}$ \\
\hline Highly unimportant & $\mathrm{HU}$ & 0.60 & 0.10 & 0.30 \\
Unimportant & $\mathrm{U}$ & 0.70 & 0.10 & 0.20 \\
Important & $\mathrm{I}$ & 0.75 & 0.20 & 0.15 \\
Very important & $\mathrm{VI}$ & 0.75 & 0.10 & 0.15 \\
Extremely important & $\mathrm{EI}$ & 0.80 & 0.10 & 0.10 \\
\hline
\end{tabular}

The linguistic expressions in Table 1 were converted into crisp values using entropy fuzzy method (Shahmardan \& Zadeh, 2013). This process is based on the determination of the entropy values of the criteria (Eq. (1)). The results from Eq. (2) represent the criteria weights. 


$$
\begin{aligned}
& e_{i}=\frac{1}{m \ln 2} \sum_{j=1}^{m}\left(u_{i j} \ln \left(u_{i j}\right)+v_{i j} \ln \left(v_{i j}\right)-\left(1-\pi_{i j}\right) \ln \left(1-\pi_{i j}\right)-\pi_{i j} \ln 2\right), \\
& w_{i}=\frac{e_{i}}{\sum_{i=1}^{m} e_{i}}
\end{aligned}
$$

where $e_{i}$ refers to techno-economic criterion $i$ entropy, and $w_{i}$ refers to the importance of techno-economic criterion $i$.

The importance of the evaluation criteria was determined based on the judgments of five experts. Their decisions were first expressed in linguistic terms using a questionnaire (Table 1). The responses of the experts are presented in Table 2 . There was no consistency in the importance for any of the criteria with respect to the five experts' judgment (see Table 5). What was obtained is that two or more experts agreed on the importance of some of the criteria. Based on Eq. (1) and Eq. (2), the weights in Table 2 were generated for the evaluation criteria. The importance of the technical and economic criteria was based on the weights in Table 2. Electricity usage, electricity saved, lamp ratings, lamp life span and $\mathrm{CO}_{2}$ were considered as technical criteria. The economic criteria were electricity cost, net present value installation cost and payback period. Based on Eq. (3) and the results in Table 2, the importance for the electricity used, electricity saved, lamp ratings, lamp life span and $\mathrm{CO}_{2}$ are $0.1983,0.1947,0.2021$, 0.2021 and 0.2027 , respectively. This showed that the most and least important technical criteria are $\mathrm{CO}_{2}$ and electricity saved, respectively. The importance of the economic criteria is 0.2502 for electricity cost, 0.2529 for net present value, 0.2487 for installation cost and 0.2482 for payback period. This shows that the least and most important economic criteria are payback period and net present value, respectively. The information in Table 2 showed that the most and least important techno-economic criteria are net present value and electricity saved, respectively.

\section{Table 2}

\begin{tabular}{|c|c|c|c|c|c|c|}
\hline Criteria & $\mathrm{D}_{1}$ & $\mathrm{D}_{2}$ & $\mathrm{D}_{3}$ & $\mathrm{D}_{4}$ & $\mathrm{D}_{5}$ & Weight \\
\hline $\mathrm{C}_{1}$ & EI & VI & EI & I & EI & 0.1118 \\
\hline $\mathrm{C}_{2}$ & EI & VI & EI & VI & EI & 0.1097 \\
\hline $\mathrm{C}_{3}$ & EI & VI & VI & VI & VI & 0.1077 \\
\hline $\mathrm{C}_{4}$ & I & I & EI & VI & EI & 0.1130 \\
\hline $\mathrm{C}_{5}$ & I & VI & VI & I & VI & 0.1111 \\
\hline $\mathrm{C}_{6}$ & I & VI & EI & EI & EI & 0.1118 \\
\hline $\mathrm{C}_{7}$ & VI & EI & I & EI & EI & 0.1118 \\
\hline $\mathrm{C}_{8}$ & I & I & VI & EI & VI & 0.1121 \\
\hline $\mathrm{C}_{9}$ & I & VI & EI & EI & VI & 0.1109 \\
\hline
\end{tabular}

Importance of the criteria in linguistic and crisp terms

$$
w_{t, e}=\frac{w_{t, e}^{g}}{\sum_{t, e=1}^{p, q} w_{t}^{g}}
$$

where $t$ and $e$ refer to technical and economic criterion $t$ and $e$, respectively, and $p$ and $q$ refer to the total number of the technical and economic criteria, respectively.

\subsection{TOPSIS method}

TOPSIS approach is adopted as a tool to aggregate the criteria values with respect to each lighting technology. This is achieved by first evaluating the normalised values in a decision matrix (Ighravwe $\&$ Oke, 2016). The normalisation of a decision matrix information can be done using their desired values (Roszkowska, 2011). However, this approach can be omitted by using Eq. (4). In order to ensure that all the data in the decision matrix are positive values, a normalising factor is considered (Eq. (5)). The results that were obtained are presented in Table 4. 


$$
\begin{aligned}
& r_{i j}=\frac{x_{i j}}{\sqrt{x_{i j}^{2}}}, \\
& x_{i j}=x_{i j}+\Delta_{j} .
\end{aligned}
$$

An illustrative example of a decision matrix for lighting technologies evaluation was obtained from the work of Gbadega (2015). This literature generated lighting technology information from a university senate building in Nigeria. The work considered CFL $\left(\mathrm{A}_{1}\right)$, T5 $\left(\mathrm{A}_{2}\right)$, E-ballast $\left(\mathrm{A}_{3}\right)$ and T8-electronic $\left(\mathrm{A}_{4}\right)$ are potential light technologies for buildings (Table 3 ).

\section{Table 3}

Performance indices of the lighting technologies

\begin{tabular}{lcccccc}
\hline Variables & & Desired value & $\mathrm{A}_{1}$ & $\mathrm{~A}_{2}$ & $\mathrm{~A}_{3}$ & $\mathrm{~A}_{4}$ \\
\hline Electricity cost/year (N Million) & $\mathrm{C}_{1}$ & $\mathrm{Min}$ & 0.395 & 0.826 & 0.554 & 0.944 \\
Electricity used (KWh/yr) Million & $\mathrm{C}_{2}$ & $\mathrm{Min}$ & 0.0089 & 0.188 & 0.126 & 0.216 \\
Electricity saved (KWh) & $\mathrm{C}_{3}$ & $\mathrm{Max}$ & 0.108 & 0.0082 & 0.0712 & -0.019 \\
NPV (N Million) & $\mathrm{C}_{4}$ & $\mathrm{Max}$ & 40.12 & 55.7 & 48.16 & 25.53 \\
Installation cost (N) Million & $\mathrm{C}_{5}$ & $\mathrm{Min}$ & 3.67 & 5.11 & 4.42 & 2.32 \\
Lamp ratings (Watt) & $\mathrm{C}_{6}$ & Min & 18 & 8 & 32 & 21 \\
Lamp life span (hr) & $\mathrm{C}_{7}$ & Max & 7500 & 10000 & 8000 & 8000 \\
$\mathrm{CO}_{2}$ emitted/yr & $\mathrm{C}_{8}$ & Min & 100,000 & 230,000 & 150,000 & 260,000 \\
Payback period (yr) & $\mathrm{C}_{9}$ & Min & 1.3 & 0.9 & 1.1 & 0.7 \\
\hline
\end{tabular}

\section{Table 4}

Normalised decision matrix for lighting technologies

\begin{tabular}{llccc}
\hline & $\mathrm{A} 1$ & $\mathrm{~A} 2$ & $\mathrm{~A} 3$ & $\mathrm{~A} 4$ \\
\hline $\mathrm{C}_{1}$ & 0.2768 & 0.5788 & 0.3882 & 0.6615 \\
$\mathrm{C}_{2}$ & 0.0284 & 0.6007 & 0.4026 & 0.6901 \\
$\mathrm{C}_{3}$ & 0.5310 & 0.4832 & 0.5134 & 0.4701 \\
$\mathrm{C}_{4}$ & 0.4577 & 0.6355 & 0.5494 & 0.2913 \\
$\mathrm{C}_{5}$ & 0.4570 & 0.6363 & 0.5504 & 0.2889 \\
$\mathrm{C}_{6}$ & 0.4182 & 0.1858 & 0.7434 & 0.4878 \\
$\mathrm{C}_{7}$ & 0.4448 & 0.5931 & 0.4745 & 0.4745 \\
$\mathrm{C}_{8}$ & 0.2557 & 0.5880 & 0.3835 & 0.6647 \\
$\mathrm{C}_{9}$ & 0.6343 & 0.4392 & 0.5367 & 0.3416 \\
\hline
\end{tabular}

Based on the information in Table 5, the weighted normalised values for technical, economic and techno-economic decision matrix were generated (Eq. (6)).

$$
v_{i j}=w_{j} r_{i j} \text {. }
$$

\begin{tabular}{|c|c|c|c|c|c|c|c|c|c|}
\hline & $\mathrm{A}_{1}$ & $\mathrm{~A}_{2}$ & $\mathrm{~A}_{3}$ & $\mathrm{~A}_{4}$ & & $\mathrm{~A}_{1}$ & $\mathrm{~A}_{2}$ & $\mathrm{~A}_{3}$ & $\mathrm{~A}_{4}$ \\
\hline & \multicolumn{4}{|c|}{ Techno-economic criteria } & & \multicolumn{4}{|c|}{ Technical criteria } \\
\hline $\mathrm{C}_{1}$ & 0.0309 & 0.0647 & 0.0434 & 0.0740 & $\mathrm{C}_{2}$ & 0.0056 & 0.1191 & 0.0798 & 0.1368 \\
\hline $\mathrm{C}_{2}$ & 0.0031 & 0.0659 & 0.0442 & 0.0757 & $\mathrm{C}_{3}$ & 0.1034 & 0.0941 & 0.1000 & 0.0915 \\
\hline $\mathrm{C}_{3}$ & 0.0572 & 0.0520 & 0.0553 & 0.0506 & $\mathrm{C}_{5}$ & 0.0924 & 0.1286 & 0.1112 & 0.0584 \\
\hline $\mathrm{C}_{4}$ & 0.0517 & 0.0718 & 0.0621 & 0.0329 & $\mathrm{C}_{7}$ & 0.0899 & 0.1198 & 0.0960 & 0.0960 \\
\hline $\mathrm{C}_{5}$ & 0.0508 & 0.0707 & 0.0611 & 0.0321 & $\mathrm{C}_{8}$ & 0.0519 & 0.1192 & 0.0776 & 0.1348 \\
\hline $\mathrm{C}_{6}$ & 0.0468 & 0.0208 & 0.0831 & 0.0545 & & \multicolumn{4}{|c|}{ Economic criteria } \\
\hline $\mathrm{C}_{7}$ & 0.0497 & 0.0663 & 0.0530 & 0.0530 & $\mathrm{C}_{1}$ & 0.0693 & 0.1449 & 0.0971 & 0.1656 \\
\hline $\mathrm{C}_{8}$ & 0.0287 & 0.0659 & 0.0430 & 0.0745 & $\mathrm{C}_{4}$ & 0.1158 & 0.1606 & 0.1388 & 0.0736 \\
\hline \multirow[t]{2}{*}{$\mathrm{C}_{9}$} & 0.0703 & 0.0487 & 0.0595 & 0.0379 & $\mathrm{C}_{6}$ & 0.1040 & 0.0462 & 0.1849 & 0.1213 \\
\hline & & & & & $\mathrm{C}_{9}$ & 0.1574 & 0.1090 & 0.1333 & 0.0849 \\
\hline
\end{tabular}

Table 5

Weighted normalised values for technical, economic and techno-economic decision matrix

The positive and negative ideal solutions for each of the alternatives are evaluated based on their desired values (Eq. (7) and Eq. (8)). The results that were obtained for the criteria positive and negative idea solutions are presented in Table 6. 


$$
\begin{aligned}
& A^{+}=\left\{v_{1}^{+}, \ldots, v_{n}^{+}\right\}=\left(\left(\max _{j} v_{i j}\right),\left(\min _{j} v_{i j}\right)\right) \\
& A^{-}=\left\{v_{1}^{-}, \ldots, v_{n}^{-}\right\}=\left(\left(\min _{j} v_{i j}\right),\left(\max _{j} v_{i j}\right)\right)
\end{aligned}
$$

Table 6

Positive and negative idea solutions for the evaluation process

\begin{tabular}{llcccc}
\hline & $v_{j}^{+}$ & $v_{j}^{-}$ & & $v_{j}^{+}$ & $v_{j}^{-}$ \\
\hline & \multicolumn{2}{c}{ Techno-economic criteria } & & \multicolumn{2}{c}{ Technical criteria } \\
\hline $\mathrm{C}_{1}$ & 0.0309 & 0.0740 & $\mathrm{C}_{2}$ & 0.0056 & 0.1368 \\
$\mathrm{C}_{2}$ & 0.0031 & 0.0757 & $\mathrm{C}_{3}$ & 0.1034 & 0.0915 \\
$\mathrm{C}_{3}$ & 0.0572 & 0.0506 & $\mathrm{C}_{5}$ & 0.0584 & 0.1286 \\
$\mathrm{C}_{4}$ & 0.0718 & 0.0329 & $\mathrm{C}_{7}$ & 0.1198 & 0.0899 \\
$\mathrm{C}_{5}$ & 0.0321 & 0.0707 & $\mathrm{C}_{8}$ & 0.0519 & 0.1348 \\
$\mathrm{C}_{6}$ & 0.0208 & 0.0831 & & Economic criteria \\
$\mathrm{C}_{7}$ & 0.0663 & 0.0497 & $\mathrm{C}_{1}$ & 0.0693 & 0.1656 \\
$\mathrm{C}_{8}$ & 0.0287 & 0.0745 & $\mathrm{C}_{4}$ & 0.1606 & 0.0736 \\
$\mathrm{C}_{9}$ & 0.0379 & 0.0703 & $\mathrm{C}_{6}$ & 0.0462 & 0.1849 \\
& & & $\mathrm{C}_{9}$ & 0.0849 & 0.1574 \\
\hline
\end{tabular}

The alternatives positive and negative ideal solutions for the problem are determined using Eq. (9) and Eq. (10), respectively. The distances of the lighting technologies from the positive and negative ideal solution under the technical, economic and techno-economic criteria are presented in Table 7.

$$
\begin{aligned}
& D_{i}^{+}=\sqrt{\sum_{j=1}^{n}\left(\bar{r}_{i j}-d_{j}^{+}\right)^{2}} \\
& D_{i}^{-}=\sqrt{\sum_{j=1}^{n}\left(\bar{r}_{i j}-d_{j}^{-}\right)^{2}}
\end{aligned}
$$

\section{Table 7}

Distances from the positive and negative ideal solutions

\begin{tabular}{lccccc}
\hline & Ideal solutions & $\mathrm{A}_{1}$ & $\mathrm{~A}_{2}$ & $\mathrm{~A}_{3}$ & $\mathrm{~A}_{4}$ \\
\hline Techno-economic & $\mathrm{D}^{+}$ & 0.0525 & 0.0900 & 0.0867 & 0.1100 \\
& $\mathrm{D}^{-}$ & 0.1065 & 0.0800 & 0.0634 & 0.0581 \\
\hline Technical & $\mathrm{D}^{+}$ & 0.0453 & 0.1497 & 0.0977 & 0.1575 \\
& $\mathrm{D}^{-}$ & 0.1598 & 0.0382 & 0.0832 & 0.0705 \\
\hline Economic & $\mathrm{D}^{+}$ & 0.7560 & 0.7936 & 0.9710 & 0.7934 \\
& $\mathrm{D}^{-}$ & 0.6647 & 0.7519 & 0.8553 & 0.6477 \\
\hline
\end{tabular}

The closeness coefficients of the alternatives are determined using Eq. (11). The results in Table 8 are used to rank the light technologies (Figure 1). The last and best ranked alternative are the alternatives with the least and highest closeness coefficients, respectively (Ighravwe \& Oke, 2016).

$$
C C_{i}=\frac{D^{-}}{D^{+}+D^{-}}
$$

\section{Table 8}

Closeness coefficient of the light technologies

\begin{tabular}{lcccc}
\hline & $\mathrm{A}_{1}$ & $\mathrm{~A}_{2}$ & $\mathrm{~A}_{3}$ & $\mathrm{~A}_{4}$ \\
\hline Techno-economic & 0.6698 & 0.4705 & 0.4222 & 0.3455 \\
Technical & 0.7793 & 0.2032 & 0.4600 & 0.3091 \\
Economic & 0.4679 & 0.4865 & 0.4683 & 0.4495 \\
\hline
\end{tabular}




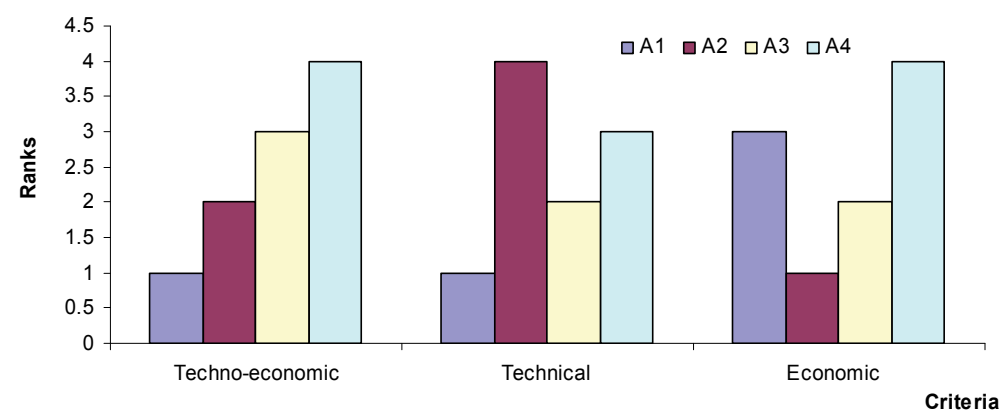

Fig. 1. Performance of the light technologies

The results presented in Fig. 1 showed that the selection of lighting technology for building depends on the type of criteria that are considered by decision-makers. It can be deduced from Fig. 1 that the criteria that are considered for lighting technology evaluation plays a significant role in the ranking of lighting technologies. The techno-economic and technical criteria results were consistent in terms of the best lighting technology for the case study. However, there are differences in the ranks for other lighting technologies (Fig. 1). The discrepancies in the technical and economic perspectives of ranking the lighting technologies justified the need for the techno-economic perspective approach for this task.

\section{Policy implications of the study}

A decision-making process is aimed at ensuring the best course of action is taken when addresses any issue. This can be achieved in an effective and efficient ways when scientific tools are used to generate relevant information for a problem. The current study has presented one of such tools for building lighting technology evaluation. This study presents the opportunity to make decision for building lighting technology selection from technical and economic and techno-economic perspectives.

\subsection{Technical criteria}

Maintenance personnel and facility managers' interests are always on the need to ensure system availability and reliability as often as possible. To achieve this, different technical criteria are considered during a decision making process. To arrive at a better judgment for lighting technology for building, decision makers depend on several technical performance indices. This study has succeeded in combining some of technical performance indices so as to equip decision makers with a single performance index for building lighting technology selection. The proposed framework also provides insights into the most and least important technical and economic criteria during lighting technology evaluation.

\subsection{Economic criteria}

The management of a system are often interested in the economic benefits that will be accrued to them for accepting a particular lighting technology. Since there are possibilities for a technology to perform best with respect to a criterion and worst for another economic criterion, it makes sense to present a framework that can be used to combine different economic criteria. This study has addressed this issue by considering pay back period, energy saving cost and net present value of different lighting technologies for public buildings. Insight on the importance of the economic criteria is provided by the proposed framework in order to improve a decision making process. This is useful when considering a single economic index as a basis for making decisions.

\subsection{Techno-economic criteria}

There is the likelihood for different building lighting technology to be selected as best technology under technical and economic criteria. This implies that there is a need for a compromise solution to this problem. In order to generate a compromise solution, this study provided a means by which decision makers can arrive at a conclusion that is scientifically based. This is necessary in order to appease the 
judgment of everybody that will be involved in a decision-making process. A detailed insight on the importance of the techno-economic criteria during policy-making can be obtained from the proposed framework.

\section{Conclusions}

This paper has presented a new framework for building light technology selection in developing countries. The proposed framework explored the unique properties of entropy fuzzy and TOPSIS methods. A real-life case study was used to demonstrate the framework applicability based on information from a University Senate building in Nigeria. Experts were asked to evaluate the importance of technoeconomic criteria to lighting technology selection. This created the opportunity to rank the criteria using entropy fuzzy method, while TOPSIS method determined the lighting technologies ranks.

This study found out that it is possible to select a lighting technology for public buildings using the proposed framework from the technical, economic and techno-economic perspectives. One natural way of extension of the proposed model is to include environmental, social and policy criteria into the proposed framework in order to guarantee the sustainability of a light technology for a building. The proposed concept for light technologies evaluation can be extended to address the issue of street light and CCTV maintenance strategy. Also, the issue of energy source for public buildings can be evaluated using the concept presented in this study.

\section{References}

Abolarin, S.M., Gbadegesin, A.O., Shitta, M.B., Yussuff, A., Eguma, C.A., Ehwerhemuepha, L., \& Adegbenro, O. (2013). A Collective Approach to Reducing Carbon Dioxide Emission: A Case Study of Four University of Lagos Halls of Residence. Energy and Buildings, 61, 318-322.

Ahmad, A.S., Hassan, M.Y., Abdullah, H., Rahman, H.A., Majid, M. S., \& Bandi, M. (2012, December). Energy efficiency measurements in a Malaysian public university. In Power and Energy (PECon), 2012 IEEE International Conference on (pp. 582-587). IEEE.

Alepuz, S., Busquets-Monge, S., Bordonau, J., Gago, J., González, D., \& Balcells, J. (2006). Interfacing renewable energy sources to the utility grid using a three-level inverter. IEEE Transactions on Industrial Electronics, 53(5), 1504-1511.

al Irsyad, M.I., \& Nepal, R. (2016). A survey based approach to estimating the benefits of energy efficiency improvements in street lighting systems in Indonesia. Renewable and Sustainable Energy Reviews, 58, 1569-1577.

Babatunde, O. M., Oluseyi, P. O., Akinbulire, T. O., Denwigwe, H. I., \& Akin-Adeniyi, T. J. (2018a). The role of demand-side management in carbon footprint reduction in modern energy services for rural health clinics. In Environmental Carbon Footprints (pp. 317-363).

Babatunde, O., Akinyele, D., Akinbulire, T., \& Oluseyi, P. (2018b). Evaluation of a grid-independent solar photovoltaic system for primary health centres (PHCs) in developing countries. Renewable Energy Focus, 24, 16-27.

Chaudhuri, S.K., \& Lovley, D.R. (2003). Electricity generation by direct oxidation of glucose in mediatorless microbial fuel cells. Nature biotechnology, 21(10), 1229.

Di Stefano, J. (2000). Energy efficiency and the environment: the potential for energy efficient lighting to save energy and reduce carbon dioxide emissions at Melbourne University, Australia. Energy, 25(9), 823-839.

Enongene, K.E., Murray, P., Holland, J., \& Abanda, F. H. (2017). Energy savings and economic benefits of transition towards efficient lighting in residential buildings in Cameroon. Renewable and Sustainable Energy Reviews, 78, 731-742.

Ganandran, G.S.B., Mahlia, T. M. I., Ong, H.C., Rismanchi, B., \& Chong, W.T. (2014). Cost-benefit analysis and emission reduction of energy efficient lighting at the universiti tenaga nasional. The Scientific World Journal, 2014.

Gbadega P.A. (2015). Techno-economic and environmental viability of retrofittings in public building, unpublished B.Sc thesis, university of Lagos, Nigeria. 
Herzog, A.V., Lipman, T.E., \& Kammen, D.M. (2001). Renewable energy sources. Encyclopedia of Life Support Systems (EOLSS). Forerunner Volume-'Perspectives and Overview of Life Support Systems and Sustainable Development.

Ighravwe, D.E., \& Oke, S.A (2016). A multi-attribute framework for determining the competitive advantages of products for business survival: A fuzzy TOPSIS approach. Total Quality Management and Business Excellence. http://dx.doi.org/10.1080/14783363.2016.1234348.

Ighravwe, D., \& Babatunde, M. (2018). Selection of a mini-grid business model for developing countries using CRITIC-TOPSIS with interval type-2 fuzzy sets. Decision Science Letters, 7(4), $427-$ 442.

Kumar, A., Jain, S. K., \& Bansal, N. K. (2003). Disseminating energy-efficient technologies: a case study of compact fluorescent lamps (CFLs) in India. Energy Policy, 31(3), 259-272.

Li, D.H., Cheung, K.L., Wong, S.L., \& Lam, T.N. (2010). An analysis of energy-efficient light fittings and lighting controls. Applied Energy, 87(2), 558-567.

Liserre, M., Sauter, T., \& Hung, J.Y. (2010). Future energy systems: Integrating renewable energy sources into the smart power grid through industrial electronics. IEEE Industrial Electronics Magazine, 4(1), 18-37.

Liu, H., \& Logan, B.E. (2004). Electricity generation using an air-cathode single chamber microbial fuel cell in the presence and absence of a proton exchange membrane. Environmental Science \& Technology, 38(14), 4040-4046.

Mahlia, T.M.I., Razak, H.A., \& Nursahida, M.A. (2011). Life cycle cost analysis and payback period of lighting retrofit at the University of Malaya. Renewable and Sustainable Energy Reviews, 15(2), $1125-1132$.

Mills, B., \& Schleich, J. (2014). Household transitions to energy efficient lighting. Energy Economics, 46, 151-160.

Omer, A.M. (2010). A review of non-conventional energy systems and environmental pollution control. Journal of Soil Science and Environmental Management, 1(7), 127-154.

Okoro, O., Chikuni, E., \& Oluseyi, P. (2008). Introducing an Energy Efficiency Awareness Programme at the University Of Nigeria, Nsukka. Industrial \& Commercial Use of Energy.

Oyedepo, S.O. (2012). Energy and sustainable development in Nigeria: the way forward. Energy, Sustainability and Society, 2(1), 15.

Panwar, N.L., Kaushik, S.C., \& Kothari, S. (2011). Role of renewable energy sources in environmental protection: a review. Renewable and Sustainable Energy Reviews, 15(3), 1513-1524.

Roszkowska, E. (2011). Multi-criteria decision making models by applying the TOPSIS method to crisp and interval data. Multiple Criteria Decision Making/University of Economics in Katowice, 6 , 200-230.

Shahmardan, A., \& Zadeh, M.H. (2013). An integrated approach for solving a MCDM problem, Combination of Entropy Fuzzy and F-PROMETHEE techniques. Journal of Industrial Engineering and Management, 6(4), 1124-1138.

Š́ri, M., Huld, T.A., Dunlop, E.D., \& Ossenbrink, H.A. (2007). Potential of solar electricity generation in the European Union member states and candidate countries. Solar energy, 81(10), 1295-1305.

Trifunovic, J., Mikulovic, J., Djurisic, Z., Djuric, M., \& Kostic, M. (2009). Reductions in electricity consumption and power demand in case of the mass use of compact fluorescent lamps. Energy, 34(9), 1355-1363.

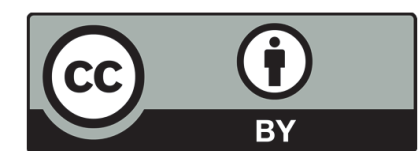

(C) 2018 by the authors; licensee Growing Science, Canada. This is an open access article distributed under the terms and conditions of the Creative Commons Attribution (CC-BY) license (http://creativecommons.org/licenses/by/4.0/). 